\title{
HISTORICAL MILESTONES WITHIN PUBLIC SECTOR ACCOUNTING IN MODERN RUSSIA
}

\author{
Nataliya G. Ivanova \\ Saint-Petersburg State University of Economics, Russia \\ Valeria I. Pilipenko \\ Saint-Petersburg State University of Economics, Russia
}

\begin{abstract}
The article briefly describes historical milestones within the process of public sector Accounting Reformation in Russia, which has proceeded since the period of reconstruction of 1990-ies. The authors provide reasons and purposes, stages, basic tools and remaining challenges of the accounting reformation, as well as specific features of financing and accounting in public sector. The present stage of the accounting reform is connected with formation of national federal accounting standards based on IPSAS. On the one hand, this new stage will facilitate domestic accounting pushing it to a new higher level and provide fair presentation of financial reporting in public sector. On the other hand, it puts new challenges for public sector accountants with reference to new professional knowledge and skills.
\end{abstract}

Keywords: accounting, public sector, IPSAS

JEL code: E 690, M 480, M490.

\section{Introduction}

Since 1998, Russia has been implementing the Programme of Accounting Reformation in compliance with international standards. Further development of the program occurred in accordance with the Concept of developing accounting and reporting in the Russian Federation for the medium term. By the order of the Central Bank of Russia, since 2004, all Russian banks have been obliged to bring Russian financial reporting in line with IFRS. Since 2012, all credit institutions, insurance companies, participants of the security market and all the companies which publish their consolidated financial statements have had to do accounting in conformity with IFRS. As of 2016, it has become evident that the business sector of Russia has adopted IFRS.

Reformation of the budgetary sphere reflects the objective processes in the development of market relations in Russia. The basic direction of the reform is convergence of budgetary and business accounting. Nowadays public sector in Russia includes government subsector, voluntary public subsector and mixed subsector. The first one comprises various kinds of entities which are state-owned companies, corporations and other organizations with government participation. Now only a part of the government subsector - government organizations - are to do budgetary accounting ${ }^{1}$ according to IPSAS. The other entities use clear IFRS format of reporting or IFRS with some corrections.

\section{Methodology}

Among the most significant research subjects and publications on the theory of accounting for the public sector we can single out the following authors: Kerry Jacobs, John Perrin, Irvine Lapsley, Jane Broadbent, James Guthrie, Andrew Goddard. These authors outlined the promising areas of the accounting methods proper and their impact both on the public sector and expected changes in it. Aldona Kamila-Sowinska outlined directions of IPSAS integration - political orientation of accountancy. A number of practice-oriented publications and much research have

\footnotetext{
${ }^{1}$ For purposes of this paper, budgetary accounting, public sector accounting and accounting for government entities are synonyms.
} 
been done in the framework of IPSAS Board consultations and also by PWC, Deloitte, Ernst \& Young auditing companies. They undertake the present-day surveys of the process of harmonizing the national accounting systems with IPSAS and their integration into European Standards.

The historical heritage and perspectives of development of public sector accounting in Russia have not been studied properly so far.

The main objective of the present paper is to prove, that public sector accounting and financial reporting system of Russia is becoming more objective, reliable and convenient for external (international) and internal users of information.

In order to achieve the above main objective, the following operational targets have been adopted:

1. Analyzing normative documents, scientific publications and the own scientific and practical experience to make up the authors' periodization of finance, accounting and reporting genesis in the public sector of Russia at the present stage.

2. Outlining specific goals, objectives, results and challenges at every stage of the development and transformation of public sector accounting and financial statements in Russia.

3. Among the characteristic features of public sector accounting one should specify: public purse property; modern forms of payment to suppliers based on information technologies at performing state / municipal jobs; showing of the effectiveness of performance of a state / municipal job in financial statements as an authentic peculiarity of the Russian public sector accounting system.

4. Determining the directions for solving current and future problems in the development of Russian public sector accounting and financial reporting.

The paper covers the period from 1993 till 2020.

The subject of this article is accounting and financial reporting system of the public sector in the Russian Federation.

The object of this article is public sector in the Russian Federation as a set of entities, obliged to carry out financial accounting and prepare particular financial statements.

The present paper hypothesizes that financial reporting of the public sector in the Russia is becoming more compatible with international accounting regulations.

\section{Specifics of public sector accounting in the Russia}

Targeted implementation of IFRS and IPSAS in the theory and practice of accounting is carried out both at the governmental and non-governmental levels, through participation of Russia, as a member or partner, in such international accounting organizations as IFAC and SAC, and through cooperation of public associations, non-government and non-for-profit organizations registered in Russia. The market of domestic experts having knowledge and skills of doing accounting and financial reporting in IFRS format has developed. Now it involves a great number of qualified specialists. These experts have always been high-paid compared with the remuneration of bookkeepers in the budgetary sphere. However, lately, evaluation of labor and skills of experts in budgetary accounting has begun to improve, their salary increasing manifold compared to the previously existing pay scale.

In Russia public sector accounting reformation takes place in 3 stages: initial, middle and current (see Figure 1). The first stage called initial has proceeded since 1993 until 2003. This period sees cores of the public sector accounting legislation.

The main acts are: Budget Code, Civil Code, "On accounting", "On not-for-profit organizations" etc. The Ministry of Finance of the Russian Federation is empowered to be a federal executive 
authority and acts as the chief methodologist for the state policy and standard-legal regulation of accounting and reporting. Issues of execution and cash service of the federal budget are within the competence of the Federal Treasury, which is a federal executive authority reporting to the RF Ministry of Finance. The Treasury of the Russian Federation acts as an information system for financial activity of public legal institutions and, in cooperation with the Ministry of Finance, takes part in the development of particular standard-legal acts, forms up and publishes reports on execution of the federal budget of Russia.

At this stage, the first steps were taken to create financial reporting in compliance with IPSAS. The middle stage was very progressive and passed from 2004 till 2010. Since that time Russia has been implementing stage-by-stage reformation of the budget process aimed at creating conditions of most efficient control over public finances and shifting priorities from "budget cost management" to "result-oriented management. One of the main directions is bringing the budgetary classification of Russia in line with requirements of international standards, as well as integration of the charts of accounts in the budgetary classification. Such chart of accounts makes it possible to account expenses subject to functions and costs.

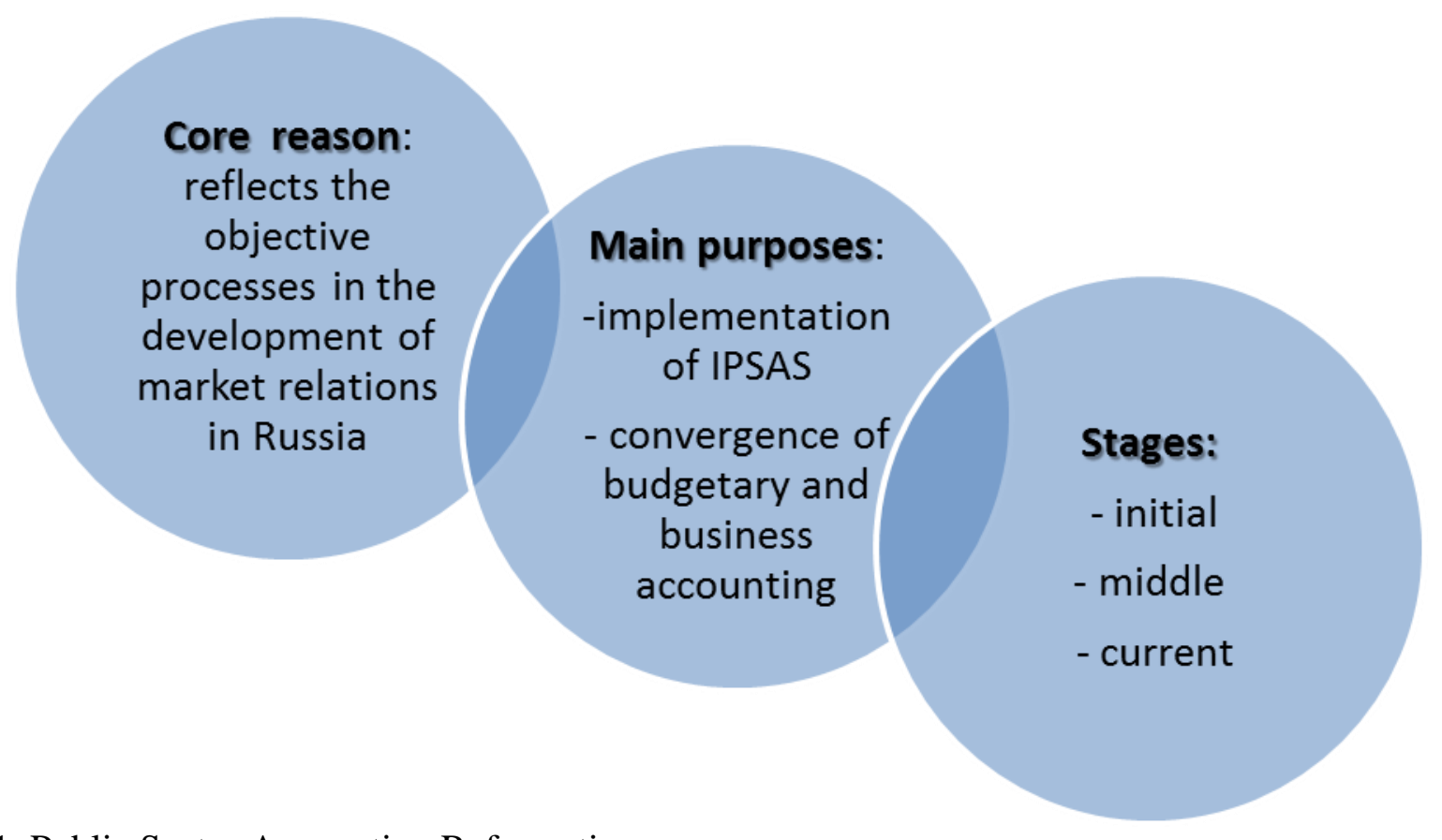

Figure 1. Public Sector Accounting Reformation

Any account in the public sector consists of 26 digits. Digits from 1 to 17 and from 24 to 26 show budgetary classification codes for incomes, expenditures, budget deficit financing sources and operations of the government administration sector (KOZGU). Digit 18 shows the code of financial security and at the same time the kind of activity. There are nine types of financing/activity (KFS). For example, commercial returns corresponding to the 18-th digit are coded as 2 , activities financed from subsidies for performance of a state task - as 4 , financing at the expense of mandatory medical insurance funds - as 7. The budgetary account includes 5 digits (from 19th to 23Rd), where 3 digits show the synthetic account of the object of accounting (for example, intangible assets, prepayment account and so on) and two other digits specify the analytical group and the type of the object of accounting (for example, land, utilities prepayment).

The Table 1 illustrates the method of forming account codes of a budgetary organization, since other types of public sector entities has different rules thereof. All the accounts of the public sector are divided into 5 main groups: non-financial assets, financial assets, liabilities, financial performance and authorization of expenditures of a subject of economic activity. Regulation of the Charts of Accounts is due to usage of the budgetary classification within the account number. The budgetary classification represents grouping of incomes, expenditures and budget deficit 
financing sources of the budgetary system. The budgetary system is used for planning and execution of budgets, accounting, and making out financial and other reports. All this provides correlation of budget indices of the whole budgetary system of Russia, though the principles of budget planning in the Russian Federation differ from those of budgetary accounting for a whole number of reasons, the most important ones being orientation at different groups of users of information, different accounting methods (cash-based for budgetary planning and accrual-based for the accounting); owners of the processes (Ministry of Finance and Treasury of Russia).

Table 1. Structure of account codes of budgetary organizations, with "Utilities prepayment account" as an example

\begin{tabular}{|l|c|c|c|c|c|c|c|c|c|c|c|c|c|c|c|c|c|c|c|c|c|c|c|c|c|}
\hline 0 & 7 & 0 & 6 & 0 & 0 & 0 & 0 & 0 & 0 & 0 & 0 & 0 & 0 & 0 & 0 & 0 & 4 & 2 & 0 & 6 & 1 & 2 & 5 & 6 & 0 \\
\hline $\begin{array}{l}\text { Section/subsection } \\
\text { codes }\end{array}$ \\
$\begin{array}{l}\text { Codes of type of income, expenditure, budget } \\
\text { deficit financing sources }\end{array}$ & KFS & Account codes & KOZGU \\
\hline
\end{tabular}

Concept of Public Sector Finance and Accounting Reformation in Russia is based on a number of principles where the main are: medium-term financial planning and result-oriented budgeting.

Medium-term financial planning implies preparation and approval of annual budgets for 3 years with in the medium-term and long-term expenditure frameworks. That's why a group of budgetary accounts named "Authorization of expenditures of a subject of economic activity" (coded as 50000) has particular analytical codes as the 22-nd digit to record the period of planning. Digit 22 is coded from 1 till 4 where 1,2,3,4 is the number of the fiscal year. Also, this budgetary account will have particular analytical codes on the place of digit 23 to record commitments (adoption or execution).

Result-oriented budgeting requires planning budget for every entity according to the goals, objectives and targeted results of activity in conformity with the goals and priorities of the government policy. So digits from 1 to 17 show the type of branch, type of the government programmes and tasks for each legal entity. The account named "Costs of execution of state task" (coded as 10900) is intended for cost accounting - calculating the costs of state/municipal tasks. Government organizations usually use absorption costing method.

The most important results of this stage are: adoption of accrual basis; introduction of new budgetary 26 digit-Chart of accounting; establishment of the accounting technique of amortization and depreciation; adoption of new financial statement such as balance sheet, income and expenditure statement, cash flow statement and explanatory note. All of these facilitate more effective control over execution of government programmers.

Public Sector financial reporting in Russia has some specific features. A balance sheet uses a vertical format with assets at the top, and liabilities and financial performance below. Assets are divided into non-finance assets and finance assets without being divided into fixed and current assets. Liabilities are classified according to the kind of accounts payable without allocating fixed and current liabilities. The last part of the balance sheet shows financial performance of the previous fiscal years, deferred revenues, prepaid expenses and provisions. Fixed assets in the balance sheet are showed at net book value. Fixed assets (tangible and intangible, and inventory) are valued at historical cost. Land is not depreciated.

At this stage basic requirements to general financial reporting in IPSAS format were implemented, and new specific objects of accounting like "public purse property" introduced. However, it should be noted that it was not possible to solve the problem of showing this object of accounting in full volume. For example, such matters as showing real cost of public purse property or transfer thereof to be used on terms of state-and-private partnership were not disclosed.

Now we are into the current stage with has been taking place since 2011. During this period new accounting legislation has been developed. The basic results of this stage are: adoption of new forms of legal entities; application of finance planning and cost accounting for state tasks; 
Implementation of new additional financial statements. They are: commitment statement and execution of public and business activities plan statement.

Nowadays public sector accounting legislation exists at 4 levels (see Table 2). The first level is for Budgetary Code and Federal Act "On Accounting". This Act determines the bases and general principles of accounting in Russia, as well as the terminology and concepts of state regulation of the accounting system for business and public sectors; specifies professional requirements to the competences of chief accountants. Basic requirements and assumptions to budget accounting in Russia include: accrual method, double-entry book-keeping, going concern assumption, consistency in application of the accounting policy, full-disclosure, objectivity, materiality and separate entity principle. The last principle means that the entity assets are accounted separately from the founder's assets.

Before development and implementation of national accounting and reporting standards in the RF public sector, there have been four instructions on accounting, two instructions on financial reporting, and one instruction on the requirements to the primary accounting documents and registers. All of these represent the second level of the Russian normative base.

Table 2. Public Sector Accounting Legislation

\begin{tabular}{|l|l|}
\hline 1-st level & RF Budgetary Code, Federal Act "On accounting" \\
\hline 2-nd level & $\begin{array}{l}\text { Unified Chart of public sector accounting; } \\
4 \text { types of Chart of accounting (for seared entities/budgetary/ autonomic } \\
\text { organizations/treasury); } \\
2 \text { types of Instruction for financial reporting (for seared entities; for budgetary } \\
\text { and autonomic organizations) }\end{array}$ \\
\hline 3-rd level & Orders and guidelines of Ministry of Finance RF, branch ministries, authorities \\
\hline 4-th level & Accounting policy of entity \\
\hline
\end{tabular}

A specific feature of financing in the public sector is involvement of two types of agents. The first includes public institutions, i.e. legislative and executive authorities financed from the federal, regional or municipal budgets, state extra-budgetary funds and other recipients of incomes according to the estimate. This form of financing is traditional for Russia and provides rigid regulation of planning of the budgetary funds and items of expenditure, in accordance with particular terms and for particular purposes. Provided public institutions do not have cash funds for execution of their obligations, their founders bear subsidiary responsibility for the debts of their institutions.

The second form of financing is relatively new and applies to two types of entities - budgetary and autonomic organizations, which receive budgetary financing in the form of grants or subsidies. In public sector accounting all money which entities have got is called revenue. Revenue can be received from business activities, from senior organizations, from other kinds of budget such as grants or subsidies. Nowadays the term "business activity" has been changed for "income bringing activity". Usually seared entities get income from federal, regional or municipal budget of Russia.

Specifics of financing in the public sector result in three types of legal entities. Each one has a different set of legal rights for execution of state tasks, for asset disposition and for business activity. They are: seared entities, budgetary and autonomic organizations. Seared entities are recipients of incomes according to the estimate. If this kind of public institutions do not have cash funds for execution of their obligations, their founders bear subsidiary responsibility for the debts of their institutions. The next types of legal entities is budgetary and autonomic organizations. These recipients of grants are provided with the rights to make independent decisions on expending budgetary funds (within the agreed sum) and returns on business activities. Autonomic organizations have more independent rights up to investing in authorized capital of commercial organizations. Founders of budgetary and autonomic organizations give or 
don't give them permission for a "big transaction". A concept of "big transaction" usually implies purchase/ sale/ lease/exchange or other business transactions. The "big transaction" should cost more than $10 \%$ of the balance's sheet total.

Financial public authorities prepare (plan) and allocate the budget among recipients of the budgetary funds within a particular region. Then they execute the budget and form consolidated statements. So for recording these transactions they use only 3 types of accounts. Bodies providing cash servicing of budgets (federal and regional treasuries) use 4 types of accounts for recording these transactions. The third kind of public sector legal entities perform a lot of functions and activities that's why for recording each type of these transactions they use a full set of accounts.

All the accounts are divided into 5 main groups: non-financial assets, financial assets, liabilities, financial performance and authorization of expenditures (Table 3). It should be noted that in the budgetary accounting one can specify three types of integrated subjects:

- financial public authorities (which prepare and execute the budgets);

- bodies providing cash servicing of budget execution;

- institutions (entities getting budgetary funds: state/municipal and executive authorities, social security funds, state/municipal seared entities, budgetary and autonomic organizations, Russian Academy of Science).

Table 3 illustrates interrelation of objects and subjects of public sector accounting for different unites of activity.

Table 3. Interrelation of objects and subjects of public sector accounting

\begin{tabular}{|c|c|c|c|c|c|}
\hline \multirow[t]{2}{*}{ Subjects of accounting } & $\begin{array}{llll}\mathbf{O} & \mathbf{b} & \mathbf{j} & \mathbf{e} \\
\end{array}$ & $\mathbf{t} \mathbf{s}$ & $\begin{array}{lll}\mathbf{0} & \mathbf{f} & \mathbf{a} \\
\end{array}$ & $\begin{array}{lllll}\text { c } & \mathbf{c} & \mathbf{o} & \mathbf{u} & \mathbf{n} \\
\end{array}$ & $\begin{array}{llll}\mathbf{t} & \mathbf{i} & \mathbf{n} & \mathbf{g} \\
\end{array}$ \\
\hline & $\begin{array}{l}\text { Non-financial } \\
\text { assets }\end{array}$ & $\begin{array}{l}\text { Financial } \\
\text { assets }\end{array}$ & Liabilities & $\begin{array}{c}\text { Financial } \\
\text { performance }\end{array}$ & $\begin{array}{c}\text { Authorization of } \\
\text { expenditures }\end{array}$ \\
\hline Financial public authorities & - & + & - & + & + \\
\hline $\begin{array}{l}\text { Bodies providing cash } \\
\text { servicing of budgets }\end{array}$ & - & + & + & + & + \\
\hline $\begin{array}{l}\text { Main administrators, } \\
\text { administrators and recipients } \\
\text { of budgetary funds }\end{array}$ & + & + & + & + & + \\
\hline
\end{tabular}

Among the unresolved issues of the current period we could outline insufficient informational content of the available financial reporting forms for evaluation of efficiency of performance of state/municipal jobs. Besides, one should mention insufficient transparency of financial statements, which is due to delays in submission or failure to submit full reports to be published on the official site www.bus.gov.ru.

\section{Development Trends in Public Sector Finance and Accounting}

Nowadays implementation of IPSAS in Russia occurs in the form of creation of a system of national accounting standards in public sector, in accordance with the orders of the RF Ministry of Finance adopted in 2015.The plan provides development of forty five IPSAS- based national standards until 2020.

For maximum accounting of the opinion of experts and scientific community, there is a procedure for public discussion of projects of federal accounting standards for the public sector, which can be looked through at http://regulation.gov.ru. The list of national standards includes available IPSAS standards adapted to the Russian accounting, i.e. Russian analogues of 32 IPSAS standards. Besides, these standards include additional national standards: Conceptual basis for development and approval of federal accounting standards of public sector entities, six standards for Charts of Accounts for various subjects of accounting in the public sector and 2 standards for rules of financial reporting. 
Eighteen federal accounting standards will come into force in January 2018. Here are the main novations of federal public sector accounting standards:

- Presentation of Financial Statements Standard implies dividing into fixed and current assets and liabilities.

- Fixed Assets Standard combines rules of Property, Plant and Equipment Standard and Investment Property Standard. Also the Standard introduces new depreciation methods and the concept of fair value of fixed assets for sale. Now public sector accounting uses straight-line depreciation method. Federal accounting standard introduces declining balance depreciation method and production based method.

- Standard named "Nonmanufactured assets" has no analogue in IPSAS. It considers only leasing accounting procedure for such type of non-financial assets as land, bowels of the earth and others not being production products.

Nowadays, besides creation of the national standard system for the public sector, the Ministry of Finance's actual tasks are development of methods of accounting and reporting, with the urgent one being convergence of information of financial reports with international standards (SNA, GFS, IPSAS) (Figure 2). The Ministry of Finance realizes the necessity of bringing the concept of "public sector organizations", delimitation and structure of institutional units of public administration and public sector in line with the international classification (SNA-2008). Therefore, respective amendments are to be made to the Federal Act FZ-402 "On Accounting".

Also, amendments are planned to the Budget Code of the Russia, which concern new authorities of the Ministry of Finance, namely, reporting in the Russian Federation in conformity with GFS international standards. Preparation of such reports in statistics should imply the knowledge on the structure and regularity of the reports, as well as availability of the information base for building system of national accounts in accordance with SNA-2008.

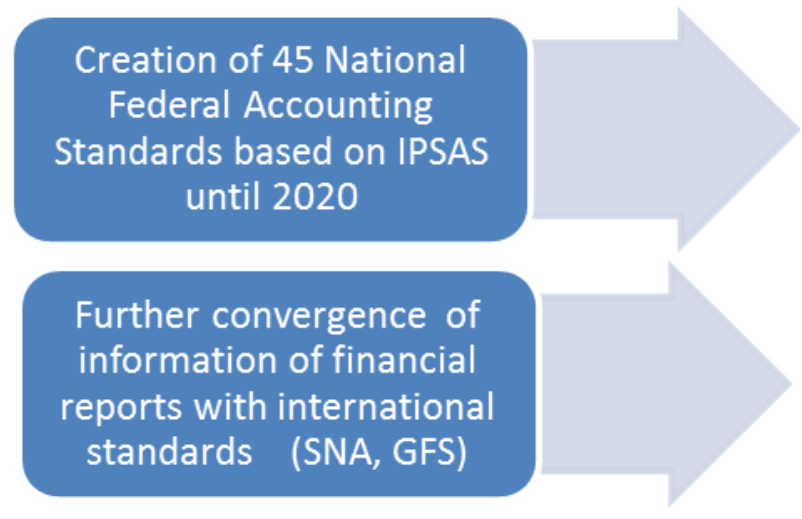

Figure 2. Development Trends in Public Sector Finance and Accounting

Currently, financial reporting in the public sector cannot be clearly referred to the category of "general purpose financial statements", since it is mostly oriented to informing superior organizations and founders, as well as government and other regulatory authorities. For a wide range of external users (as required by IPSAS), the informational component of official financial reporting is rather complicated.

Besides, it should be noted that at the present time, the formed consolidated reporting for the public sector of Russia is mainly provided without information on state-owned companies, corporations and other organizations with government participation. Therefore, the RF Ministry of Finance is developing new procedures of consolidates reporting for the RF public sector.

Also, in prospect there is a trend of convergence between accounting in the public sector and budgetary planning. 
All these new challenges require high-skilled experts in financing and accounting of the budget sphere, who have lately been in great demand in Russia.

The authors are convinced that in order to solve the above-mentioned problems it is necessary:

1. To add a form showing information on effectiveness of performance of state/municipal job to the general financial reports (appendix to balance sheet).

2. Ministry of Finance of RF should develop model recommendations to accounting of a wide range of operations concerning public purse property evaluation. The most actual are such accounting operations as inflow and outflow as a result of inventory, commodity exchange operations, decommissioning, indemnification; transfer of public purse property for compensatory and free rent, as well as under concession agreements.

3. To provide a system of penalties for subjects of public sector financial reporting for delayed or incomplete submission of the reports on the site www.bus.gov.ru.

\section{Conclusion}

The present stage of accounting reforming is connected with formation of federal accounting standards based on IPSAS. On the one hand, this new stage will facilitate domestic accounting pushing it to a new higher level, and allow the users to get fair, high quality and objective information from the financial statements. On the other hand, it will put new challenges for public sector accountants with reference to new professional knowledge and skills.

The methodology described in the present publication has provided the following:

- making up the author's periodization of finance, accounting and reporting genesis in the public sector of modern Russia, as well as specifying historical benchmarks of public sector accounting and reporting transformation.

- determining basic goals, tasks, results and unresolved tasks of each stage in the development of public sector accounting and reporting.

- outlining specifics of the Russian public sector accounting and reporting system.

- stating the directions for solving current and future problems of public sector finance, accounting and reporting development.

Thus, the hypothesis of the present paper can be considered as proven.

\section{References}

Broadbent J., Guthrie J. (1992). Changes in the Public Sector: A Review of Recent "Alternative" Accounting Research. Accounting, Auditing \& Accountability Journal, vol. 5, no. 2, pp. 3-32.

Broadbent J., Guthrie J. (2008). Public Sector to Public Services: 20 Years of "Contextual" Accounting Research. Accounting, Auditing \& Accountability Journal, vol. 21, no. 2, pp. 129169.

Collection of information related to the potential impact, including costs, of implementing accrual accounting in the public sector and technical analysis of the suitability of individual IPSAS standards 2013/S 107-182395, PwC.

Available on-line at www.pwc.com/gx/en/psrc/pdf/pwc-implementing-epsas.pdf

Draft Federal Standards for public sector entities.

Available on-line at www.minfin.ru/ru/performance/ budget/sfo. (In Russian)

Federal Law № 402-FZ of 6 December, 2011 “On Accounting”.

Available on-line at www.old.minfin.ru/en/accandaudit/index.php

Goddard A. (2010). Contemporary public sector accounting research - An international comparison of journal papers. The British Accounting Survey, no. 42, pp. 75-87.

IPSAS in your pocket. 2013 Edition, Deloitte. 
Available on-line at www.iasplus.com/en/publications/public-sector/dt-ipsassummary-2013

Ivanova N. G., Pilipenko V. I. et al, (2013). Budget reformation of the public sector for a state (municipal) enterprise. S-Petersburg: Publications of SPb State University of Economics, (In Russian)

Jacobs K. (2012). Making Sense of Social Practice: Theoretical Pluralism in Public Sector Accounting Research. Financial Accountability \&Management, vol. 28, no. 1, pp. 1-26.

Kamela-Sowińska A. (2015). "Accounting Integration Issues of EU Member States. Euqulibrium, Quarterly Journal of Economics and Economic Policy, vol. 10, no. 2, pp. 223-236.

Lapsley I. (1988). Research in Public Sector Accounting” Accounting, Auditing \& Accountability Journal, vol. 1, no. 1, pp. 21-33.

Overview and comparison of public accounting and auditing practices in the $27 \mathrm{EU}$ Member States Prepared for Eurostat Final Report 19 December 2012, Ernst \& Young.

Available on-line at www.ec.europa.eu/eurostat/documents/1015035/4261806/study-on-publicaccounting-andauditing-2012.pdf/5ad43e2b-2ba7-4b05-afab-d690fc2ad9dd

Perrin J. (1981). Accounting Research in Public Sector. M. H. Bromwich and A. Hopwood (eds.). Essays in British Accounting Research. London: Pitman.

The Future Governance of the International Public Sector Accounting Standards Board (IPSASB) PUBLIC CONSULTATION January 2014.

Available on-line at www.oecd.org/gov/budgeting/IPSASB-Consultation-Paper.pdf 